\title{
CORRUPTION AS A NEGATIVE SOCIAL PHENOMENON HINDERING THE ECONOMIC DEVELOPMENT OF THE STATE
}

\author{
Zhanna Semchuk' ${ }^{1}$, Iryna Zharovskaya ${ }^{2}$, Olga Merdova ${ }^{3}$
}

\begin{abstract}
The purpose of this article is to analyse the current state of fighting corruption as one of the negative phenomena that hinder the economic development of the state, parasitizing the whole body of Ukrainian society. It is emphasized that existing in society, being a product of social relations, corruption permeates various social spheres of society, deforms various groups of social relations. It is appropriate that a narrowly chosen approach to preventing such a negative phenomenon significantly reduces the effect of such an activity and, as a result, does not enable to form an autonomous system that would be resistant to other accompanying risk factors. It is worth paying attention to the problems that are gaining the objective acuteness in recent times and are to oppose the state regulation of the economy by administrative methods and the so-called "freedom" of the development of economic relations. The need for operational intervention in the economy by state institutions through the adoption of managerial decisions, taking into account the growth of the global economic crisis, produces a separate phenomenon - economic corruption. However, the strong link between the social and economic spheres indicates the need for a comprehensive counteraction to such a socially dangerous phenomenon. Along with this, the determinants of the spread of corruption in Ukraine are characterized by their social nature, and less by an economic one. It is stressed that corruption can be considered as a kind of social corrosion, which erodes and destroys public authorities, in particular, the state and society as a whole. The article reveals the content and significance of corruption, its types and forms. It is indicated that corruption - a social phenomenon that has a social conditionality and rules of social development and influence on social processes. The social nature of corruption manifests itself first of all in the fact that it has historical origins and social preconditions. Practical importance of the scientific research is to find out the causes and consequences of corruption for the economic development of the state, which is extremely important for improving the current legislation of Ukraine, which cannot be effective without conducting a high-quality anti-corruption expertise, built on a clear mechanism for conducting such an examination and reliable, validated methodologies. Methodology. The methodological foundations of the study of corruption are determined by a set of methods of scientific knowledge, which allow considering this problem as a multidimensional, multidisciplinary phenomenon. The research strategy, which is the basis of the integrated approach, grounds, first of all, on the following methodological principles: the formulation of a general theoretical concept; the development of cross-cutting concepts and categories that ensure the unity of the approach to the research object.
\end{abstract}

Key words: corruption, corruption offence, anti-corruption expertise, economic development, causes and consequences of corruption, anti-corruption measures.

JEL Classification: K10, Z18

\section{Introduction}

The adoption of democratic principles of the rule of law, equality of all before the law today has become one of the priority tasks of our state. The basis for this was a series of events that took place in Ukraine and forced the state to go through the way of the leading countries of the world with a developed democracy, in particular, European ones. However, despite all the efforts, there are a number of problems that hinder the processes of full and qualitative development of the state, which must be opposed by all, both the state and the public.

\footnotetext{
Corresponding author:

${ }^{1}$ Lviv University of Business and Law, Ukraine.

E-mail: business law@ukr.net

${ }^{2}$ Lviv Polytechnic National University, Ukraine.

E-mail: irazhar@ukr.net

${ }^{3}$ Donetsk Law Institute of the Ministry of Internal Affairs of Ukraine, Ukraine.

E-mail: olga.merdova@ukr.net
} 
One of such problems was the problem of corruption, which is now parasitizing throughout the whole large "organism" of society. The Great Explanatory Dictionary of Modern Ukrainian Language for a reason interprets the term "parasite" as "an organism that lives within another organism or grows into it and is fed by its tissues, juices, etc." (The Great Explanatory Dictionary of Modern Ukrainian Language, 2009).

The scale of the spread of corruption in the world and the growing attention of the international community to this negative phenomenon have turned corruption into a global problem of our time.

Due to the active position of a number of international organizations and public propaganda, corruption has become perceived not only as a problem of corrupt states but also as a problem of those states and foreign companies that corrupt them.

Today, anti-corruption measures are also being implemented by governments of individual states and by various international, civil, and non-governmental organizations.

A large number of countries have introduced in government policy a wide array of anti-corruption measures that deserve extraordinary attention, study, and use.

As a result, the so-called global anticorruption consensus emerges and develops gradually in the global community. In the fight against this evil, the anticorruption consensus claims to combine efforts between various social and political forces, in particular, between the left-wingers and the right-wingers, between liberals and conservatives, between globalists and antiglobalists (Andrianov, 2011).

Therefore, corruption, as an extremely negative social phenomenon, requires a profound scientific study and analysis. This is primarily determined by the fact that most of the problems that affect from time to time different spheres of our society, especially in the unsuccessful resolution of some economic problems, crises that have taken place and are taking place against the backdrop of political confrontation in the country, are directly related to the influence of the phenomenon of corruption on these processes. The urgency of studying this phenomenon lies in its phenomenal ability to exist in each country, regardless of historical development, level of the economy, social development, and availability of legislative framework, which should counteract this. Its uniqueness consists in the ability to constantly develop, transform into a variety of new forms of manifestation, to improve, to adapt to the existing legal framework, and to coexist along with the obligatory principles inherent in a legal, democratic state: legitimacy, the rule of law, equality of all before the law, observance of rights and freedoms of citizens.

The global community has been genuinely interested in this phenomenon for the past few decades, and foreign experts and scientists are making a lot of effort in order to capture all aspects of this phenomenon. Since the phenomenon of corruption erases any interstate and inter-scientific frontiers and, at the same time, absorbs by its influence almost all spheres of life, its study takes place comprehensively and consistently, globally, and attention, first of all, is given to the nature of the emergence and development of tools, due to which it is possible, if do not overcome, then at least localize and minimize its scale and impact on society.

\section{Definition of corruption, its possible forms and types}

The phenomenon of corruption for history, law, and society is not new. Proceeding from the conclusions of the research of the science of history, this phenomenon existed from ancient times, from the moment of the emergence of the state and the creation of its bodies endowed with authority and administrative powers (Miroshnychenko, 2010). However, throughout the history of its existence, this phenomenon has one characteristic feature - it is harmful in legal, social, economic, and other aspects.

The term of corruption is derived from the combination of the Latin words correi and rumpere: correi - the obligatory involvement of several representatives of one of the parties in one case, and rumpere - to violate, break, damage, cancel. So an independent term was formed - corrumpere (Bartoshek, 1989), which means participation in the activities of several (not less than two) persons, whose purpose is to "spoil", "destroy", "damage" the normal development of the judicial process or the process of managing the affairs of society (Tiemnov, 1994).

Most often, the term "corruption" applies to the bureaucratic apparatus and political elite. According to one of the existing definitions, corruption is the failure of the state, with the help of incentives, to direct the useful interest of a person in a productive direction.

Considering the issue of corruption and the possibilities of legal influence on it, K. Surkov (Surkov, 1991) emphasizes that corruption should be understood as the use in any form by officials of state, executive, judicial power, institutions and organizations of economic management, public associations of their official position for obtaining property, services or privileges for themselves or third parties.

A well-known Russian scholar N. Kuznietsova emphasizes that corruption should be considered not only as legal but also as moral relations (Kuznietsova, 1993). O. Dudorov, who in his scientific publication considers corruption as a social, economic, and moral evil, follows the same position (Dudorov, 1994).

V. Hvozdetskyi, who notes that corruption is a complex and multidimensional (legal, economic, political, moral and psychological) social phenomenon, studied corruption as a social, psychological, and moral 
phenomenon. The social nature of corruption manifests itself in the fact that it: has a social conditionality (is a product of social life); has its social price, which society pays for the existence of corruption, significantly affects the most important social processes; has historical origins and global character, is a legal, economic, political, psychological, and moral phenomenon; has the ability to adapt to social realities, constantly mimic and modify (Hvozdetskyi, 2012). O. Tylchyk considers corruption as the determinant of economic shadowing while defining the complex social, economic, and legal nature of such phenomena (Tylchyk, 2017).

Many scientists considering issues of the essence of the phenomenon of corruption, the causes of its occurrence and existence, as well as counteracting this negative phenomenon, judge corruption to be one of the obligatory signs of organized crime, emphasizing the fact that in a number of cases, organized crime and corruption are so much closely connected that this gives grounds for highlighting corruption as one of the signs of organized crime. This opinion is expressed by M. Melnyk (Melnyk, 2001), O. Tylchyk (Tylchyk, 2017), L. Arkusha (Arkusha, 2000), P. Bilenchuk, S. Yerkenov, A. Kofanov (Bilenchuk, Yerkenov, Kofanov, 1999), O. Kvasha (Kvasha, 2010), O. Ohorodnykov (Ohorodnykov, 2011), O. Kalman (Kalman, 1997), O. Zhovnir (Zhovnir, 2009) and others.

The notion of corruption is defined by Ukrainian law, in particular, Art. 1 of the Law of Ukraine "On Prevention of Corruption", as "the use by a person specified in part one of Article 3 of this Law of his/her authority or related opportunities for the purpose of obtaining an unlawful benefit or acceptance of such benefit or acceptance of a promise/offer of such benefit for himself/herself or other persons or, accordingly, the promise/offer or provision of unlawful benefit to a person specified in part one of Article 3 of this Law or at his/her request to other natural or legal persons in order to persuade this person to misuse his/her authority or related opportunities" (On Prevention of Corruption, 2014).

Instead, many scholars believe that it is hardly possible to give a single, comprehensive definition of corruption, which would accurately distinguish between corrupt phenomena and those that are not corrupt in all cases.

Consequently, a number of scholars, whose views we support, believe that one of the most erroneous interpretations of corruption is the attempt to squeeze it in the framework of exclusively criminal manifestations (Tylchyk, 2017). A significant number of authors believe that corruption as a social phenomenon is a much larger formation than the totality of purely criminogenic manifestations. In real life, there are many other its types that have never been considered criminal.

Taking into account the abovementioned thoughts, we believe that conditionally corruption can be classified using a variety of features, criteria, and peculiarities of manifestation. In particular, one can distinguish the following types of corruption:

- administrative (and petty as its kind);

- business (business, entrepreneurial, financial);

- corruption related to the pressure on the state (aggression, capture);

- political.

Administrative corruption should be understood as intentional distortion in the process of mandatory enforcement of the current rules of law, rules, etc., in order to give preference to the parties concerned.

Business corruption arises when business and government interact. Business corruption is, in essence, payment by entrepreneurs, businessmen in cash or material assets to civil servants in matters relating to their activities.

Corruption related to the pressure on the state (aggression, "capture") serves as a kind of corruption, which in the world practice is considered as activities of individuals, groups or companies, both in the public and private sectors, in order to influence the formation of legislation and other instruments of state policy.

Political corruption is a special kind of corruption. Political aspects of the phenomenon of corruption are extremely multifaceted and contradictory. One should agree with A. Y. Frantsuz and A. A. Frantsuz that in this case, civil society is the most effective mechanism for preventing and combating corruption (Frantsuz A. Y., Frantsuz A. A., 2013).

At the same time, in addition to these negative facts of the impact of corruption on state-public relations, it is appropriate to draw attention to the opinion of I. P. Holosnichenko, who notes that corruption acts negatively influence the rights and freedoms of man and citizen. Public services are provided not according to their law but according to the rules of organized criminal activity (Holosnichenko, 2001).

\section{Legal regulation of the prevention of corruption in Ukraine}

Corruption is one of the main factors of political and socio-economic instability in Ukraine, which has been repeatedly mentioned in the speeches of deputies of the Verkhovna Rada of Ukraine, the President of Ukraine, and the heads of the Government. The existence of the phenomenon of corruption among the representatives of the government and management apparatus poses a threat to the stable socio-economic development of the state.

There is no need for additional evidence that corruption affects the system of public administration, its implementation principles, generates contempt for the civil service and mistrust of civil servants, and contributes to the decline of the authority of state power since corruption can exist only among people with authority. 
The state in the early 90s of the XX century voluntarily abandoned most of the control functions, which to some extent contributed to the emergence of a managerial vacuum in the economy and social sphere. As a consequence of this, it became obvious that the then "unregulated market economy" generated unprecedented levels of corruption, as a result of it state ownership virtually pricelessly turned into private hands. This was facilitated by the mass adoption of corruption laws and by-laws, which were lobbied by certain groups that penetrated the authorities.

The systemic character of corruption in Ukraine in addition to other reasons is determined by the nature of Ukrainian legislation, which is marked by a controversial, multivariate interpretation of individual norms, conflicts, gaps, etc.

The legal basis for combating corruption includes the international legal acts and legal acts of Ukraine. The international mechanism for the prevention of corruption has a significant impact both on the development of international anti-corruption cooperation and on the development of national anticorruption legislation.

The Law of Ukraine "On Prevention of Corruption" as of 14.10.2014 determined the legal and organizational principles of the functioning of corruption prevention system in Ukraine, the content and procedure for the application of preventive anti-corruption mechanisms, rules for the elimination of the consequences of corruption offenses (On Prevention of Corruption, 2014).

In addition to the said Law, a number of otherlegislative acts have an anti-corruption direction, in particular: Laws of Ukraine "On National Anti-Corruption Bureau" on 14.10.2014 (On National Anti-Corruption Bureau, 2014), "On Access to Public Information" on 13.01.2011 (On Access to Public Information, 2011), "On Appeal of Citizens" on 02.10.1996 (On Appeal of Citizens, 1996), "On Prevention and Counteraction of Legalization (Laundering) of the Proceeds from Crime, Terrorist Financing, and the Financing of Proliferation of Weapons of Mass Destruction" on 14.10.2014 (On Prevention and Counteraction of Legalization (Laundering) of the Proceeds from Crime, Terrorist Financing, and the Financing of Proliferation of Weapons of Mass Destruction, 2014), and a number of others.

At the same time, in order to increase public confidence in state institutions, faithful and effective performance by civil servants of their duties, the Law of Ukraine "On Civil Service" as of 10.12.2015 was adopted (On Civil Service, 2015). The Decision of the National Agency on Corruption Prevention "On Commencement of Work of the System for Submission and Public Disclosure of Declarations of Persons Authorized to Perform Functions of State or Local Self-Government" on 10.06.2016 № 2 (On Commencement of Work of the System for Submission and Public Disclosure of Declarations of Persons Authorized to Perform Functions of State or Local Self-Government, 2016) and the Order of the Ministry of Justice of Ukraine as of 23.06.2010 №1380/5 “On Approval of Methodology for Anti-Corruption Expertise of Drafts of Regulatory Legal Acts" (On Approval of Methodology for AntiCorruption Expertise of Drafts of Regulatory Legal Acts, 2010) are also of great importance for the process of preventing corruption in public authorities.

\section{The anticorruption expertise of laws and regulations as a significant obstacle to corruption}

It is obvious that a qualitative statutory legal act can only be created as a result of the complex application of a diverse range of expert assessments, among which not only anti-corruption but also legal, independent, scientific, linguistic, financial feasibility, social, gender, etc.

Instead, anti-corruption expertise is aimed, firstly, at detecting corruption provisions, and secondly, at fulfilling a preventive role in relation to corruption manifestations.

The purpose of anti-corruption expertise is to identify and eliminate the legal preconditions for corruption (corruption-causing factor), which in essence is identified by the elimination of defects of the legal provision, the legal formula (Kudriavtsev, 2007).

A corruptogenic provision generates or can lead to corruption offenses. Such a provision does not correspond to the purpose and tasks of legal regulation since the ordinary legal provision is aimed at regulating the most important social relations, effective influence on them by means of coercive measures provided for by the law, intended for repeated implementation (observance, application, execution, use, implementation). The corruptogenic provision, formally having the same functional purpose of a legal provision, in practice reduces the effectiveness of influence on social relations.

Elimination of corruptogenic provisions is possible in the process of rule-making activity of the body that applies the act (rule-making body) or the implementation of law enforcement functions by authorized state bodies. In essence, the elimination of corruptogenic factors in legal provisions is aimed at increasing the effectiveness of legal influence on social relations and law enforcement (Kudashkin, 2011).

\section{Conclusions}

Summarizing the foregoing, we can state that corruption is a phenomenon that is constantly evolving, transforming, adapting to the conditions of development of legislation, society, and state, while its essence and negative influence remain unchanged. Changing the types and forms of corruption offenses is carried out in order to prevent the impact of the existing 
anti-corruption measures aimed at counteracting these phenomena and their limitations. Given the abovementioned, in our opinion, it is necessary to supplement existing anti-corruption legislation with definitions of possible forms of corruption behaviour, as well as adequate responsibility for such acts.

In the context of our study, it should be noted that solving the problems of effective counteraction to corruption largely depends on how correctly and deeply its essence is understood. Clarification of the essence of corruption is extremely important in the theoretical and practical terms. From the scientific point of view, the importance of this issue is determined by the fact that it is the key to any research of corruption in the field of jurisprudence, as well as in other branches of science, including sociology, political science, and economics.
In addition, it is a derivative for scientific research: statement of the research problem, determination of its area, subject-matter, purpose and objectives, and methodology selection etc. depend on its solution.

Determining the essence of corruption eventually proves the reliability of the results of scientific research since this point in comparison with all other points of the problem of counteraction to corruption is a key, basic for all others. The importance of this issue for practical activity in the field of combating corruption lies in the fact that the formation of a strategy and such an activity, the formulation of its goals, the determination of the forces and means of their achievement, the content and level of statutory, material, financial, and other support depend directly on the correct understanding of the essence of corruption.

\section{References:}

The Great Explanatory Dictionary of Modern Ukrainian Language (as amended) (2005). Compiled and edited by V. T. Busel. K.; Irpin: PTF “Perun”, 1728 p.

Andrianov, V. D. (2011). Corruption as a global problem: the past and the present. Moscow: Economics, 304 p.

Miroshnichenko, D. V. (2010). Criminal law impact on corruption. M.: Yuridlitinform, 200 p.

Bartoshek, M. (1989). Roman Law. Concepts. Terms. Definitions. M.: Yuridicheskaia Literatura. 448 p.

Temnov, E. I. (1994). Corruption. Origin of the modern concept. Urgent issues of the theory and practice of the fight against organized crime in Russia: materials of Scientific-Practical Conference. Moscow Institute of the MIA of Russia. M., p. 14-15.

Surkov, K. V. (1991). On the concept of corruption and the possibilities of legal impact on it. Methodological problems of education and personnel work in internal affairs bodies and internal military forces. SPB, p. 31-37.

Kuznietsova, N. F. (1993). Corruption in the system of criminal offences. Moscow University Herald. Series 11. Law, 1, 21.

Dudorov, O. L. (1994). Corruption. Variations on bribery. Viche, 8, 5.

Hvozdetskyi, V. D. (2012). Corruption as social, psychological, and moral phenomenon. Current Problems of State and Law, 63, 139-145. URL: http://nbuv.gov.ua/UJRN/apdp_2012_63_21

Tylchyk, O. V. (2017). The essence of a legal determination of the concept of "shadow economy". Visegrad Journal on Human Rights, 2, 186-190.

Melnyk, M. I. (2001). Corruption: the essence, concept, countermeasures: monograph. K.: Atika, 304 p.

Tylchyk, O. V. (2017). Preconditions for determining the ratio of shadow economy and corruption in Ukraine. Jurnalul juridic național: teorie şi practică, 3, 58-60.

Arkusha, L. (2000). Corruption - element of organized crime activity. Law Herald, 2, 118-121.

Bilenchuk, P. D., Erkenov, S. E., Kofanov, A. V. (1999). Transnational crime: state and transformation: Study guide. Edited by Acad. K.: Atika, 272 p.

Kvasha, O. O. (2010). Corruption and organized crime: justification of interrelation. Constitutional State. K., 21, 335-342.

Ohorodnyk, O. O. (2011). Corruption - a burden on the stage of development of Ukrainian statehood. Bulletin of the Ministry of Justice of Ukraine, №10 (October), 153-155.

Kalman, O. (1997). Interrelation of organized crime and corruption in the economy. Journal of the National Academy of Legal Sciences of Ukraine, 4, 188-190.

Zhovnir, O. Z. (2009). Interrelation of organized crime and corruption in contemporary society. Fight against organized crime and corruption (theory and practice), 21, 323-330.

On Prevention of Corruption: Law of Ukraine on 14 October 2014 № 1700-VII Gazette of the Verkhovna Rada of Ukraine (GVR), 2014, № 49, Art. 2056.

Tylchyk, O. V. (2017). Establishing the correlation of the concept of "counteraction to the shadowing of the economy” with related legal concepts. Jurnalul juridic național: teorie şi practică, 6, 7-75.

Frantsuz, A. Y., Frantsuz, A. A. (2013). Civil society as an effective mechanism for preventing and counteracting corruption. Legal Bulletin of "KROK” University, 15, 11-18. URL: http://nbuv.gov.ua/UJRN/Pvuk_2013_15_4 Holosnichenko, I. P. (2001). Overcoming corruption as a levelling of rights and freedoms of man and citizen. International law and national legislation: Collection of research papers. International Institute of Linguistics and Law; Ed. by: V. L. Chubariev (head) and others. K.: Pravovi Dzherela, 1, 39-48. 
On National Anti-Corruption Bureau: Law of Ukraine on 14 October 2014 № 1698-VII. Gazette of the Verkhovna Rada of Ukraine, 2014, № 47, Art. 2051.

On Access to Public Information: Law of Ukraine on 13 January, 2011 № 2939-VI. Gazette of the Verkhovna Rada of Ukraine, 2011, № 32, Art. 314.

On Appeal of Citizens: Law of Ukraine on 2 October 1996 № 393/96-BP. Gazette of the Verkhovna Rada of Ukraine, 1996, № 47, Art. 256.

On Prevention and Counteraction of Legalization (Laundering) of the Proceeds from Crime, Terrorist Financing, and the Financing of Proliferation of Weapons of Mass Destruction: Law of Ukraine on 14 October 2014 № 1702-VII. Gazette of the Verkhovna Rada of Ukraine, 2014, № 50-51, Art. 2057.

On Civil Service: Law of Ukraine on 10 December 2015 № 889-VIII. Gazette of the Verkhovna Rada of Ukraine, 2016, № 4, Art. 43.

On Commencement of Work of the System for Submission and Public Disclosure of Declarations of Persons Authorized to Perform Functions of State or Local Self-Government: Decision of the National Agency on Corruption Prevention on 10.06.2016 № 2. Official Herald of Ukraine, 2016, № 55, Art. 1930.

On Approval of Methodology for Anti-Corruption Expertise: Order of the Ministry of Justice of Ukraine on 24.04.2017 № 1395/5. URL: http://old.www.minjust.gov.ua

Kudriavtsev, V. L. (2007). Anti-corruption expertise: issues of theory and methodology of the procedure. The anticorruption expertise of laws and regulations and their drafts. The expertise of regulatory legal acts and their drafts with a view to corruptogenicity: content, meaning, procedure: collection edited by O. S. Kapinus and A. V. Kudashkin. M., p. 6. Kudashkin, A. V. (2011). Problems of organization and conduct of anti-corruption expertise by prosecution agencies. Journal of Russian Law, 2, 25-26. 